\title{
Conifer encroachment study will inform efforts to preserve and restore North Coast oak woodlands
}

\author{
$\mathrm{O}$ \\ California's North Coast, landowners \\ have noticed for decades the steady \\ expansion of conifer stands into grassy \\ oak woodlands.
}

"It's one of those things that creeps up on you not a radical change, but just a clearly shifting trend," said Dina Moore, a rancher in the Van Duzen River watershed near Eureka.

Conifer encroachment on the North Coast matters because it shrinks the already limited acreage of

\section{A 1987 study estimated that $30 \%$}

of the white oak woodlands in one region of Redwood National Park had been lost to encroachment by Douglas fir since 1850. oak woodlands, one of the state's iconic landscapes. Oak woodlands are valuable for several reasons, including grazing, hunting and habitat for oak-associated wildlife communities. Several counties are prepar-

ing oak woodland conservation plans, and the U.S. Fish and Wildlife Service and the Natural Resources Conservation Service have been providing grants to landowners to pay for tree removal to counter the trend.

But these efforts have been hampered by both a

Encroaching conifers obscure a stand of oak in Redwood National Park. poor understanding of the extent of conifer encroachment in the region and a lack of research on the best ways to address it. A 1987 study estimated that $30 \%$ of

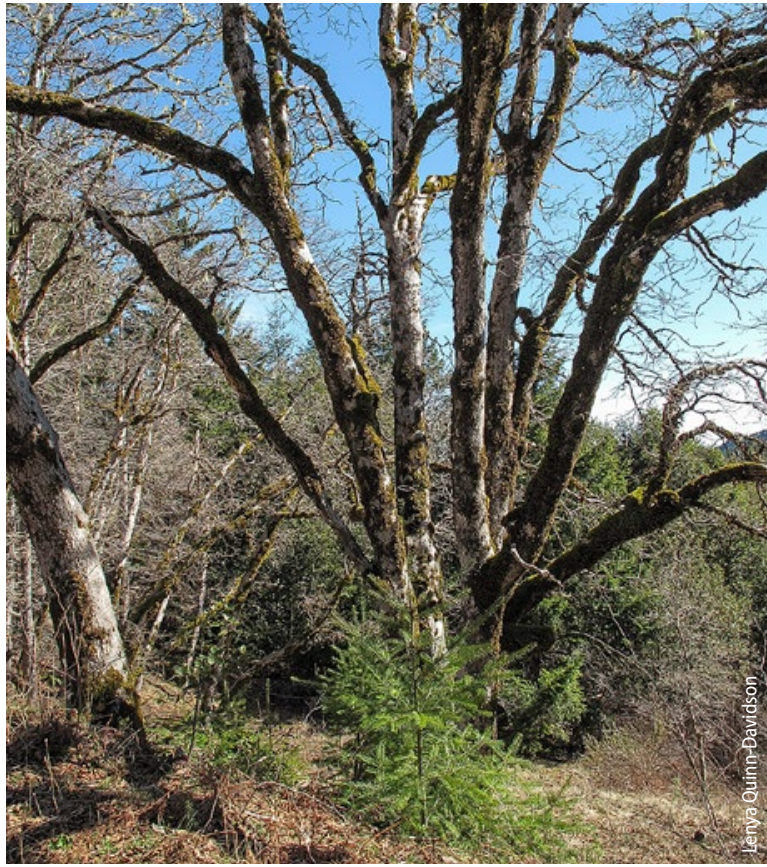

Fire suppression helps to create conditions that allow conifers to sprout and mature among oaks, as in this woodland in Redwood National Park.

the white oak woodlands in one region of Redwood National Park had been lost to encroachment by Douglas fir since 1850, but there has been limited research since on the encroachment issue.

Better information is coming this fall, with the publication of results from a three-year investigation funded by UC Agriculture and Natural Resources (UC ANR) and led by UC Cooperative Extension (UCCE) researchers.

The project, "Tools for a changing landscape: Understanding disturbance and vegetation dynamics in Northern California oak woodlands," is using aerial photography and satellite data to generate the first comprehensive map of oak woodland areas in Humboldt and Mendocino counties. Researchers will compare current conditions with historic photos and other data, along with field measurements of tree ages and other characteristics, to evaluate the extent and impact of Douglas fir encroachment.

The project has established field sites in multiple locations to study climate, moisture and other conditions that may influence encroachment patterns. The information gathered will also help researchers to 
predict how climate change may affect the encroachment process.

The California black oak and Oregon white oak woodlands of the North Coast are fire-adapted, meaning that they depend on frequent, low to moderate intensity fires to prevent establishment of invading fire-sensitive vegetation - including conifer species such as Douglas fir - and to help provide the conditions necessary for new oaks to sprout and develop to maturity.

Decades of fire suppression have allowed Douglas fir and other conifers to become established in oak woodland areas, many of which contain oaks that are hundreds of years old. The study has found that the encroachment trend accelerated in several of the research sites starting in the 1960s, though it's not clear why. The Douglas fir invasion is a part of the overall trend of forest densification that has been observed throughout the western United States in the absence of natural disturbance regimes like fire.

Reversing the encroachment process is difficult, in part because conifer stands create conditions that make it more difficult to use fire as a management tool. For instance, Douglas fir trees become fire resistant as they grow in size, reducing the effectiveness of prescribed fire and adding another layer of complexity to already costly oak woodland restoration strategies. As a result, manual removal of some trees may be necessary before prescribed fire can be used to help restore and maintain oak woodland conditions.

"Once the conifers get a foothold, the oaks lose," said Yana Valachovic, a UCCE forest advisor, director for UCCE Humboldt and Del Norte counties and one of the principal investigators on the project. "The oaks are not regenerating, and the amount of oak woodland area is shrinking as a result of the encroachment."

Larger conifers can be removed by manual thinning, but that work tends to be very labor intensive and costly, particularly in remote areas, said Moore, the landowner. In addition, the trees that need to be removed generally have little or no market value as timber, and many areas have no access to biomass energy markets. "Landowners would like to have an option for commercial utilization of the conifers, to not have to rely on government funded cost-share programs alone," said Valachovic.

Guidance on management changes that landowners could take to prevent encroachment in the first place would help. One of the goals of the conifer encroachment project, Valachovic said, is to develop a decision support system to help landowners determine what management approaches are likely to be most effective on their property.

California's forest management policies make the conifer encroachment problem even knottier.

Under the California Forest Practice Rules, established by the 1973 Forest Practices Act, landowners are required to replant conifer stands after harvesting trees. In conifer forests managed for timber, the rule makes sense. But it doesn't currently include an exception for cases where a landowner is trying to restore an oak woodland by removing conifers.

Valachovic and her UC ANR colleagues have gone before the California Board of Forestry to testify about the need for a rule change and also authored a policy brief arguing for a rule change. There is a precedent for amending the Forest Practice Rules to enable restoration; in 2012, the state Board of Forestry adopted an amendment allowing conifers to be removed from aspen stands and meadows for restoration purposes. Later this year, the state Legislature will consider a proposal to amend the rules in a similar way for oak woodlands. CA

\section{— Jim Downing}

\section{Prescribed fire can help to stop the spread of Douglas fir trees into open oak woodlands, as in this burn in Redwood \\ National Park. But Douglas fir become more fire resistant as they mature.}

Policy constraints and unfavorable difficult to remove established conifer of oak.

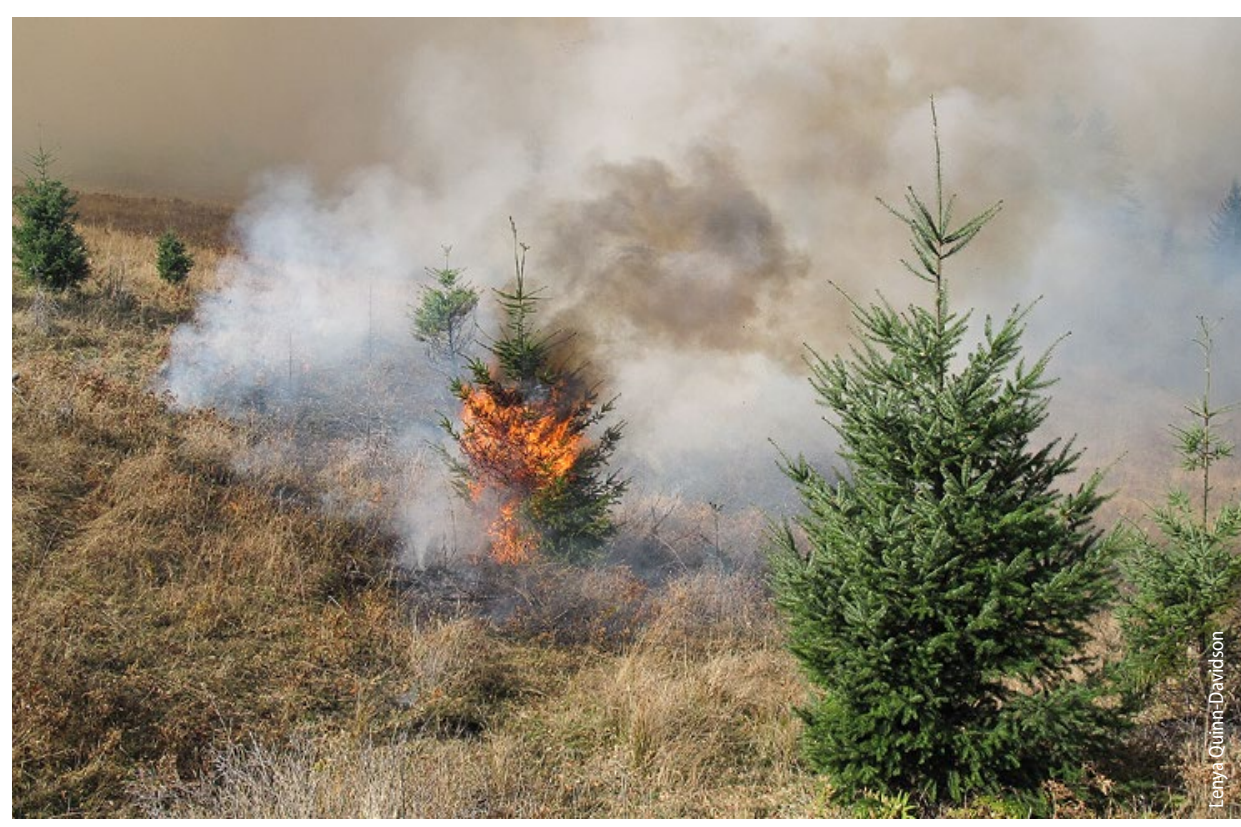

